\title{
中国の双台河口湿地灌溉葦原における塩分変動及び水 収支の考察

\author{
FIELD STUDY ON SALINITY AND WATER BALANCE OF THE IRRIGATED REED \\ COLONY IN SHUANGTAI ESTUARINE WETLAND, CHINA
}

\author{
林俵 1 ・石川忠晴2・楊鳳林 3 ・張樹深4 \\ Qian LIN, Tadaharu ISHIKAWA, Fenglin YANG and Shushen ZHANG \\ 1学生会員 修(工) 東京工業大学 環境理工学創造専攻（†226-8502 横浜市緑区長津田町4259） \\ 2フェロー会員 工博 東京工業大学教授 環境理工学創造専攻（广226-8502 横浜市緑区長津田町4259） \\ 3 非会員 大連理工大学教授 化工与環境生命学部（１116024 中国遼寧省大連市） \\ 4非会員 大連理工大学教授 化工与環境生命学部 ( ₹116024 中国遼寧省大連市)
}

\begin{abstract}
The effects of irrigation process on reed colony of Shuangtai Estuarine Wetland in Liaoning Provence, China, are discussed with the field investigation (salinity distribution, reed growth of shoot height, density, and above biomass) and hydrological measurement (water levels inside and outside the reed colony). Reed production proves to have an optimum at 5\% salinity. The salinity will decrease below 5\%o in growing season due to irrigation, and after drainage the salinity level will rise. The observation on water levels suggests that the ratio of interception to rainfall by reed body in the growing period is about 0.4. Evapotranspiration rate is estimated by surface water balance equation without inflow and outflow. The calculation result also indicates that the irrigation is required for keeping water balance before raining season in middle July.
\end{abstract}

Key Words: Reed colony, Salinity, evaporation, transpiration, rainfall interception, Liaohe Delta

\section{1. はじめに}

大河の河口デルタでは水路が複雑に分岐し，また有機 性に富む細粒土砂が堆積することから，豊かな生態系を 持つ広大な湿地(河口湿地)が出現しやすい. 中国沿岸に は総計面積が $1.2 \times 10^{6} \mathrm{ha}$ 河口湿地が分布している。 そ の中で杭州湾より北方の河口湿地には約 $5.7 \times 10^{5} \mathrm{ha}$ の莘 群落があり，東南アジアからシベリアまでの区域で移動 する渡り鳥の営巣地および中継地となっている.

しかし近年の沿岸地域における人口増加に伴って開発 圧力が増大し，田畑や養殖池などへの転用が進められつ つある. また上流域の取水量増加により湿地流入量が減 少し, 生態系が劣化しつつある. 湿地環境保全が世界的 課題であるといっても, 経済発展の欲求を完全に止める ことは難しい. そこで，自然環境保全と地域経済発展を 両立する湿地利用の在り方が社会的課題となっている1).

本研究で対象とする双台河口湿地は, 中国東北部から 渤海湾に注ぐ遼河の河口デルタ上にあり，128,000haが 国家自然保護区になっている. その中に世界最大の蔁原 (83,000ha)が含まれており, 丹頂など渡り鳥の中継地に なっている.ただし国家自然保護区であっても生産活動 が全く禁止されるわけではなく，葦原の一部を開墾して 灌溉し水田や養殖池に利用することも行われている.

ところで中国では葦を原料とした製紙が伝統的に行わ れている. 現在の製紙産業は木材パルプが主体になって きているが，今でも非木材パルプのシェアは $20 \% を$ 占め, 植物種別では麦わら(62\%), 蕫(11.4\%), 竹(10.6\%)の順に なっている ${ }^{2)}$. 草本類は樹木や竹に比べて成長が早く, それらの利用は自然環境保全といら点で優れている。 た葦は麦に比べて繊維質が多いため紙質が良い.

ただし河口湿地の地下水に含まれる塩分は葦の成長を 阻害する ${ }^{3)}$. また自然状態の莘原では成長が土䁃の乾湿 変動の影響を受ける ${ }^{4)}$. そこで葦の品質向上のために灌 溉が実施されている.このような葦原の利用と管理は, 湿地の自然環境と調和した地域発展の一つのモデルにな ると考えられる.ただし現在の灌溉方法は多分に経験的 である. そこで本研究では，双台河口湿地の塩分状態と 灌泊期における水量バランスについて,現地調査の結果 に基づき考察した. 


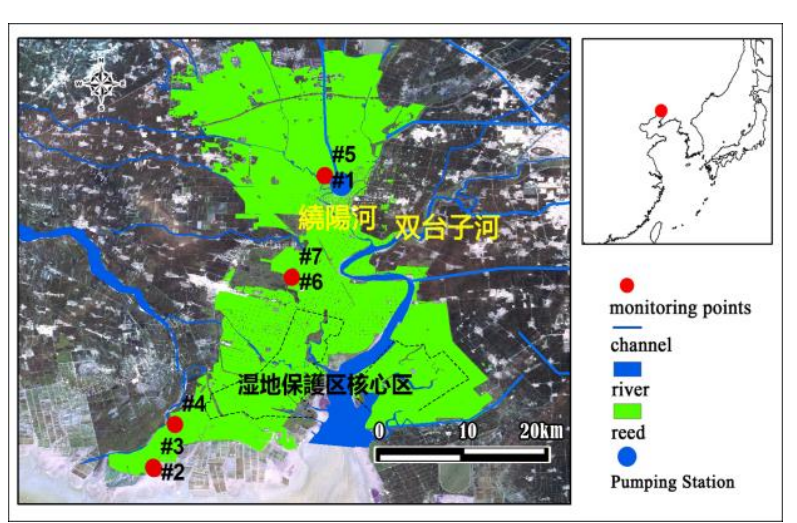

図-1 対象地域の位置と平面図

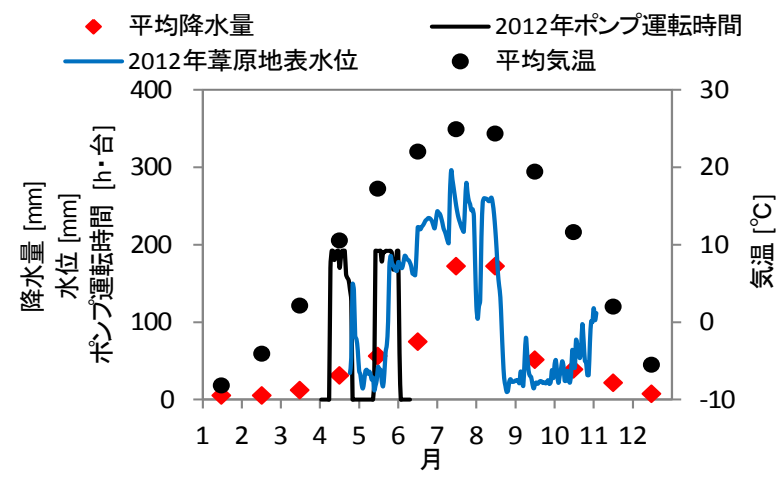

図-2 平均気温と降雨量

\section{2. 対象地域の概要}

双台河口湿地葦原の位置と平面図を図-1に示す。緑色 の部分が葦原, 青色は河川と主要な灌溉水路である. 調 查地点を赤丸で示している，灌溉水は双台子河(遼河本 川) と繞陽河(遼河支流)から取水されている．灌溉葦原は いくつかの大区画に区分され，区画ごとに設置されたポ ンプで給水されている. 大区画は低い堤防でさらに小区 画に区分され，手動の取水門および排水門から個別に給 水・排水される. 個々の小区画への分水は手動で “適宜” 行われている.

図-2に湿地近傍の盤錦市における過去20年間の平均的 な年間気温 $(○)$ と降雨量 $(\diamond)$ を示す。また，青線は図-1 における観測点\#1の灌溉区画の水位変化，黒線は同区画 を含む大区画に通水するポンプの運転時間(台数 $\times$ 時間) である。

同地域の気温は11月中旬から3月中旬まで水点下であ り，表層土壌は4月まで涷結している。また降水量は7月, 8月に集中するが，葦の成長期は5月下旬から7月下旬で あり ${ }^{5}$, 前半の水量が不足気味となる。 そこで4月に予備 灌溉を行い，表層土壤を融解するとともに土壤塩分を低 下させ，5月に本灌溉を開始する。 それ以降は降雨と蒸 発散により水位が適当に保たれていれば取水・排水を行 わない，7月に入ると雨量が急増するので，管理水深を $250 \mathrm{~mm}$ 程度として排水する。旧暦立秋(新暦の8月中旬)
の5日前に排水門を開き水位を低下させ，大きな降雨が なければ一週間ほどで排水を完了する．ただし8月～9月 上旬は降雨が比較的多いので地面は湿潤・乾燥を繰り返 す. 葦の刚り取りは地表が凍結した12月に行われる.

\section{3. 葦の生育と塩分環境}

\section{1. 葦の生育度と土壌塩分の相関}

\section{(1) 葦の塩分耐性}

Lissner・Schierup ${ }^{6}$ はデンマークの海岸での調査結果か ら，根部付近の土壌水塩分が $15 \%$ 以上上場所では葦が開 花前に枯死すると報告している．また温室試験から地下 水塩分が5\%。までは莘の成長に影響がないと結論した。 また Lissnerら ${ }^{7}$ は緯度の異なるデンマークとスペインで 採取された葦の屋外生育実験を行い，塩分5\%o程度まで は葦の相対成長に対する影響はないとしている.

Mauchamp ・ Mésleard ${ }^{8)}$ は地中海周辺の9か所の湿地帯に おいて地下水塩分と葦の高さおよび密度との相関を調べ, サイト条件にもよるとが，全体的には塩分と成長速度に 負の相関があるとしている. Hartzendorf・Rolletschek ${ }^{9)}$ は, ドイツの三か所で採取した葦を用いた室内実験から，塩 分0～1.5\% 。成長率が高く，10\%。にると著しく低下し， 35\%。死亡することを示した.

\section{(2) 現地調査の概要}

灌溮終了後に地面が露出した2013年8月30日〜8月31日 に，図-1に示す7地点で葦の生育状況と土壤塩分の関係 性を調べた，北から順に，\#1は灌浤区域，\#6は非灌漑区 域, \#7は灌溉水路辺縁の灌溉水で冠水する地点, \#4, \#5は非灌濐区域，\#2は葦原のすぐ外の干潟区域である. まず $1 \mathrm{~m} \times 1 \mathrm{~m}$ 範囲を設定して葦の本数を調心゙，続いて成 長が平均的だと思われる5本を選択して地面直上で刈り 取り, 重量, 先端の穂を除いた茎高, 地面直上の茥径を 計測した。また乾燥重量を後日計測した。

\section{（3）土䉴塩分の計測法}

土垬中に含まれる可溶性塩類濃度の表示法は必ずしも 定まっていないが，近年は，土壤を蒸留水で飽和させ， 減圧濾過あるいは遠心分離で抽出した液体の電気伝導度 $(E C e)$ が指標としてよく用いられる ${ }^{10)}$.しかしこの方法 は時間とコストが比較的かかる。そこで1:5希釈溶液の 電気伝導度計測值 $\left(E C_{1: 5}\right)$ もよく用いられる.

本研究では $E C_{1: 5}$ を計測し，Caイオンが特に多くない silt loam土壤についてKhorsandi・Yazdi ${ }^{11)}$ が提案した次式 により $E C e$ を求めた。

$$
E C_{e}=k E C_{1: 5}+b, \quad k=5.28, b=0.88
$$

なお， $k$ と $b$ の值については種々の調査があるが ${ }^{12)}$, 本 湿地の土壌特性 ${ }^{13)}$ はKhorsandi・Yazdiの条件に近い.

地点\#1 \#6においてコアサンプラーで土壤を表層から 
表-1＼cjkstart葦の成長度および土壌塩分調査の結果

\begin{tabular}{cccccccc}
\hline 場所 & $\# 1$ & $\# 2$ & $\# 3$ & $\# 4$ & $\# 5$ & $\# 6$ & $\# 7$ \\
\hline 高さ $[\mathrm{cm}]$ & 218.4 & - & 83.4 & 118.2 & 154.6 & 165.4 & 249.2 \\
太さ $[\mathrm{cm}]$ & 0.57 & - & 0.52 & 0.33 & 0.41 & 0.42 & 0.52 \\
湿潤重量 $[\mathrm{g} / 5$ 本] & 340 & - & 135 & 70 & 150 & 130 & 325 \\
乾燥重量 $[\mathrm{g} / 5$ 本] & 174.9 & - & 43.3 & 37.5 & 78.6 & 61.6 & 176.2 \\
含水率 $[\%]$ & 48.6 & - & 67.9 & 46.4 & 47.6 & 52.6 & 45.8 \\
密度 $\left[\right.$ 本/ $\left./ \mathrm{m}^{2}\right]$ & 46 & - & 13 & 110 & 23 & 16 & 35 \\
\hline $\mathrm{EC}_{1: 5}[\mathrm{~ms} / \mathrm{cm}](10 \mathrm{~cm})$ & 0.64 & 4.75 & 4.36 & 1.54 & 1.81 & 1.43 & - \\
塩分 $[\% 0](10 \mathrm{~cm})$ & 2.74 & 16.61 & 15.28 & 5.76 & 6.67 & 5.39 & - \\
\hline
\end{tabular}

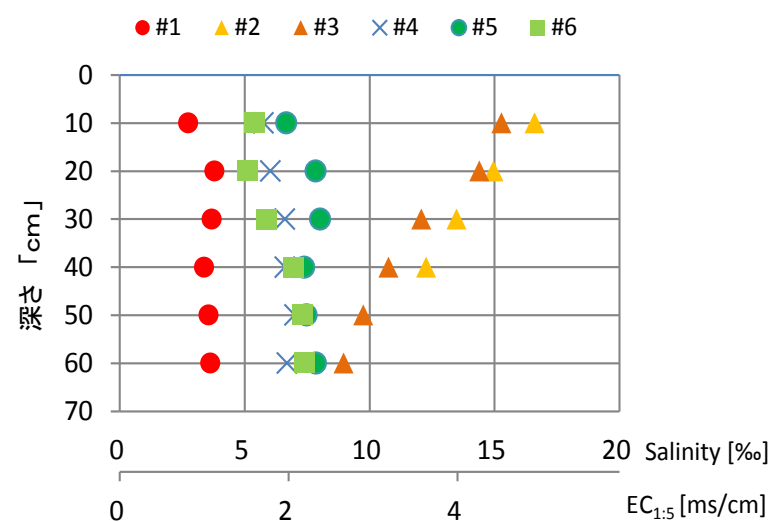

図-3 各地点の塩分鉛直分布

$60 \mathrm{~cm}$ ま゙゙ $10 \mathrm{~cm}$ 間隔で採取し，大連理工大学で $E C_{1: 5}$ を測

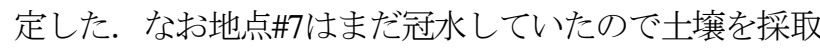
できなかった. 本研究では $E C e$ を浅層地下水の電気伝導 度 $E C_{T}$ とみなし ${ }^{14)}, E C_{T}$ から式(2)により $25^{\circ} \mathrm{C}$ における電 気伝導度ECを求めた後, 式(3)により塩分に換算した ${ }^{11)}$.

$$
\begin{gathered}
E C=E C_{T}\left[1+\frac{(298.2-T)}{49.7}+\frac{(298.2-T)^{2}}{3728}\right] \\
T D S=0.64 \times E C
\end{gathered}
$$

ここにTDS(Total Dissolved Solids)は総溶解性塩分で, 単 位はg/L(=\%)である。なお $E C の$ 単位はms $/ \mathrm{cm}$ である.

\section{(4) 調査結果}

莘の成長度および土壤塩分調査の結果を表 1 に示寸. なお地点井では莘は生育せず，地点井 7 冠水のため土壌 塩分は計測できなかった. まず莘の生育状況を比較する と, 灌溉地点(\#1) と灌溉水路際(\#7)で良いことがわかる。

図-3に各地点の塩分鉛直分布を示寸．横軸には計測し たEC $1: 5$ と，式(1)〜(3)を用いて換算した塩分(TDS)を示し ている. 内陸の非灌溉地点である\#4，\#5，\#6の塩分は表 層で若干低く，50cm深辺りで一定(約7.5\%)になる．一方 海に近い\#2 と\#3は表層塩分が高いが，深くなると他の地 点の值に漸近する. 双台湿地蔁原は地盤が極めて平坦で あることから，地下水塩分は7～8\%で一定であり，地点 ごとの表層土壌塩分は表流水塩分に規定されているので はないかと考えられる，一方，灌湛莘原の表層塩分は3 〜4\%。であり，前述した莘の塩分而性の值から，灌筂が

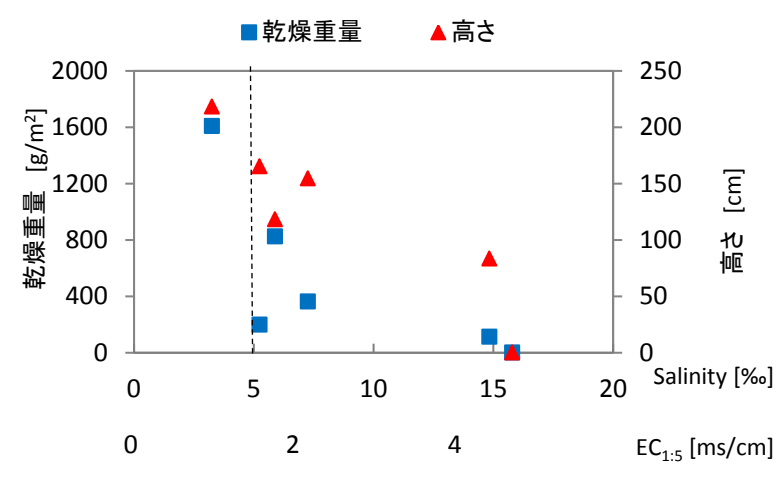

図-4 塩分と単位面積当たりの葦乾燥重量及び高さの関係

莘の生育に良い効果をもたらしている可能性が大きい.

双台湿地の蔁の毛細根は深度 $20 \mathrm{~cm}$ までの表層に集中 している ${ }^{13)}$. そこで図 $-3 の 10 \mathrm{~cm} 〜 20 \mathrm{~cm}$ の塩分平均值と 単位面積あたりの蔁乾燥重量および高さの関係を図-4に 示す. 土壌水の塩分が高くなると, 高さの変化はわずか だが，乾燥重量は大幅に減少する. なお図中の点線は, Lissner ${ }^{6)}$, 7 が生育実験から求めた塩分影響の限界 $(5 \%)$ を表している。

\section{2. 灌溉葦原における塩分変化}

図-3に示した塩分鉛直分布は灌泊が終了して間もない 時に計測された。 そこで灌溉の影響の季節性を調べるた めに，地点\#1で過去に計測した結果と比較する．計測時 期は，灌溉前の状態(2012年4月21日)，灌溉直後で表層が 湿潤した状態(2013年8月30日 ; 図-3と同じ)，および灌溉 終了後約3か月経過して地表が乾燥した状態(2012年11月 3日)である。

結果を図-5に示す．計測が時間順になっていないため, 季節変化を完全に捉えているとは言えないが，その特徴 を以下のようにみることができる．灌泊期前(赤)には塩 分が全層で高い状態にあり, 灌激期直後(青)には5\%以下 になっている. その後の乾燥過程(緑)で塩分は上昇する. この結果と前述の図-4から, 灌溉による塩分低下が莘の 生産に有効であることがわかる。なお灌溉期間には地表 が水没しているため，その間の土畩塩分変化は捉えられ ていない. 

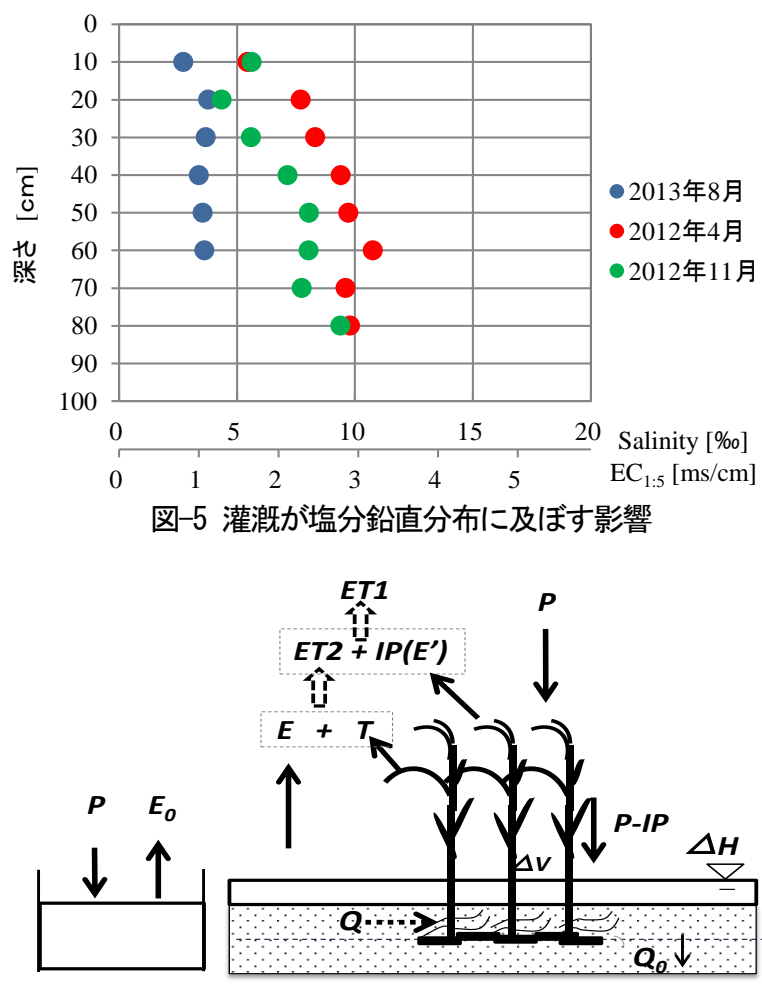

図-6 岸外葦原の水収支要素

\section{4. 灌漑葦原の水収支}

\section{1. 計算方法}

\section{（1）水収支式}

灌泊莘原の水収支に関わる要素として本研究で考える 要素を図-6に示す。ここでは日単位の鉛直一次元的水収 支を考えている. 左側は後述する莘原外の水槽で，Pは 日降雨量, $E_{0}$ は水面からの蒸発量である. 右側は莘原の 水分移動を表しており， $\Delta H$ は一日の湿地水面変化量; $P$ は降雨量 ; IPは莘の葉等による遮断される降雨量で, 降 雨終了後に直接蒸発する $\left(\right.$ 遮断蒸発量 $\left.E^{\prime}\right)$ と考える; $E$ は 莘原内水面からの蒸発量 ; $Q$ は莘による地下水の吸水量 $\Delta V$ はのうち莘の体組織に貯留される水量, $T$ は莘から の蒸散量, $Q_{0}$ は深層への浸透量である.

莘の葉に遮断された水量も含めて空中に回帰寸る蒸 発散量をETI，それを含めない水量（葦原水面からの 蒸発量と莘の蒸散量だけの合計）をET2とすると, 以 下の式を得る.

$$
E T 1=P-\Delta H-\Delta V-Q_{0}=E T 2+I P
$$

双台湿地における土質調查 ${ }^{13}$ によれば，土壌は平均粒 径 $0.005 \mathrm{~mm}$ のsilt loamで, $30 \mathrm{~cm}$ 以深の透水係数は $6 \mathrm{~cm} /$ day であり，動水勾配が1の場合にこの速度で流れ得る。し かし双台湿地の地下水位は浅く，灌泊期には全層飽和状 態にある．また灌溉区では広い範囲にわたって水位がほ ぼ等しい.このことから鉛直浸透量 $Q_{0}$ は無視できると考

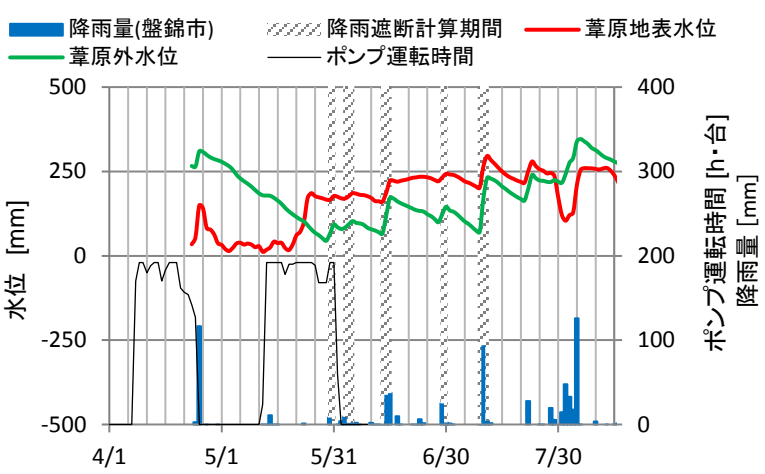

図-7 葦原内 - 外の水位記録と雨量

えられる．また前述したように灌激期直後の調査では莘 の重量は $3128 \mathrm{~g} / \mathrm{m}^{2}$ であり, 莘総重量の全部が水であった としても雨量換算で $3.1 \mathrm{~mm} に$ 過ぎず，検討期間内の他の 項目の水量に比べて2オーダ小さい. そこで水収支式の 中の莘体内水分蓄積量 $\Delta V$ を無視する.

\section{(2) 計算期間}

2012年の灌泊期における水量関係の計測量を図-7に示 す. 細黒線は灌溉区ポンプ管理者から入手した「ポンプ 台数 $\times$ 運転時間」である. 5月10日に観測区域の大区画 へのポンプ給水が開始され，5月31日に終了した。 また 菩原内水位が5月 20〜25日下旬に上昇していることから， 手動堰により当該小区画に給水がなされたと考えられる. その後は給排水がなく, 莘原内外の水位は降雨日に同時 に上昇している．しかし7月10日の降雨で水位が管理水 深 $(250 \mathrm{~mm})$ を超え，その後の水位莪減率が以前に比心 てかなり大きいことから，排水が行われた可能性が大き い.7月22日の降雨の後も同様である。また7月29日には, その後の大雨に備えて事前排水を行っている. そこで, 灌泊取水が終了した5月31日から，排水があったと思わ れる7月10日の直前までの水収支を検討した.

\section{2. 計算結果と考察}

\section{（1）葦による降雨遮断}

図-7の青棒は湿地観測点から $30 \mathrm{~km}$ にある盤錦気象 局の日降雨量である．莘原外水槽水位（緑線）は盤 錦でまとまった降雨のあった日には概ね対応した上 昇を示している，そこで葦原外水槽水位が $20 \mathrm{~mm}$ 以 上（図でハッチを付したの日）上昇した日を検討対 象とした。まずそれらの日の水面蒸発量をPenman 法15)により計算したところほぼ3mm/dayであったの で，水位上昇量に $3 \mathrm{~mm}$ を加えて日降雨量とした。 ま た葦原内については(2) で述べる方法により0.46を乗 じた $1.4 \mathrm{~mm}$ を莘原内水位上昇量に加えた。 それらの 比から, 降雨遮断率を求めた結果を, 葦の高さの変化と ともに図-8に示す．莘がまだ十分成長していない6月初 旬に降雨遮断率は多少小さいが，概衫0.4で安定してい る. そこで $I P=0.4 P$ とする.

\section{（2）蔁原水面からの蒸発}




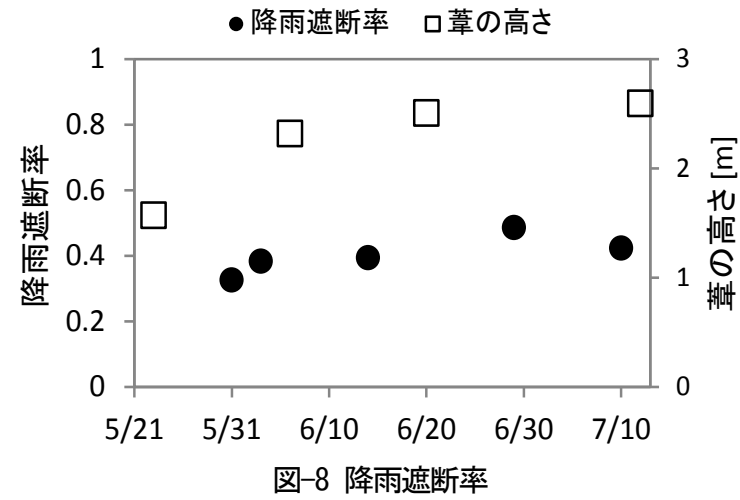

莘原外の蒸発量は次のように推定した，無降雨日の蒸 発量は，盤錦で無降雨であった日の莘原外水槽の水位減 少量とした。また降雨日については式(5)，(6)に示す Penman式 ${ }^{15)}$ からの推定值の平均 $(3 \mathrm{~mm} / \mathrm{d})$ とした. 以上 の值から期間内の莘原外蒸発量の日平均值を計算したと ころ $5.5 \mathrm{~mm} / \mathrm{d}$ となり, Penman式を全期間に対して適用し た $E_{p}$ の期間平均值 $(5.1 \mathrm{~mm} / \mathrm{d})$ とほぼ一致した.

$$
\begin{gathered}
\lambda E_{p}=\frac{\Delta}{\Delta+\gamma}\left(R_{n}-G\right)+\frac{\gamma}{\Delta+\gamma} f(u)\left(e_{s}(T)-e_{a}\right) \\
f(u)=0.26(1.0+0.537 u)
\end{gathered}
$$

ここに， $E_{p}$ は可能蒸発量; Rnは正味放射量 $\left(\mathrm{MJ} \mathrm{m}^{-2} \mathrm{day}^{-1}\right)$, $e_{s}(T)$ は飽和水蒸気圧 $(\mathrm{kPa}), \Delta$ は飽和水蒸気曲線の傾き $\left(\mathrm{kPa}{ }^{\circ} \mathrm{C}^{-1}\right), \quad \gamma$ は乾湿定数 $\left(\mathrm{kPa}^{\circ} \mathrm{C}^{-1}\right), \lambda$ は蒸発潜熱 $(\mathrm{MJkg}$ $\left.{ }^{1}\right), G$ は地中熱流量 $\left(\mathrm{MJ} \mathrm{m} \mathrm{m}^{-2} \mathrm{day}^{-1}\right), u$ は水平風速 $\left(\mathrm{ms}^{-1}\right), \mathrm{T}$ は日平均気温 $\left({ }^{\circ} \mathrm{C}\right)$ である。 なお，本研究のように長期の 収支計算の場合には $R_{n}$ に比較して $G$ を無視ができると考 えられている ${ }^{16}$ ので, 本研究でも $G=0$ とする.

$E T 1$ とET2は，葦原内外水位変化から式(4)を用いて計 算できる。その結果，計算期間の平均值はETIが $3.9 \mathrm{~mm} / \mathrm{d}, E T 2 か ゙ 2.3 \mathrm{~mm} / \mathrm{d}$ よった. したがって莘原から の蒸発散量ETIは開放水面蒸発量 $E_{0}$ の約 0.7 倍となった.

莘原内の水面からの蒸発量 $E$ と莘からの蒸散量 $T$ を分 けて取り扱うために, $E$ と莘原外部水槽から蒸発量 $E_{0}$ の 関係を，式(5)，(6)に基づき検討した。 式(5)は第1項が熱 の授受の影響を表し，第2項が風の影響を表す．植生が 密生しかつ湿潤条件である場合には水蒸気圧と風速に係 わる第2項は十分小さいと示唆されている17).

風速の影響は線形なので，ここでは検討期間における 平均風速を考える. 盤錦気象局における同期間の平均風 速は約 $3 \mathrm{~m} / \mathrm{s}$ であった。密生度の高い莘原の場合，莘原内 風速を莘原外の0.1倍と推定している例 ${ }^{18)}$ があるが，ここ では風速を $0 \mathrm{~m} / \mathrm{s}$ から莘原外風速の 0.5 倍 $(1.5 \mathrm{~m} / \mathrm{s})$ までの 範囲にあると仮定して莘原内の蒸発量減少比を式(6) よ り求めたところ，0.38～0.69倍となった.

一方，莘原内の熱の授受による変化についてRitchie ${ }^{17)}$ が次式を提案している.

$$
\lambda E=\frac{\Delta}{\Delta+\gamma}\left(R_{n}-G\right) \exp (-\alpha L A I)
$$

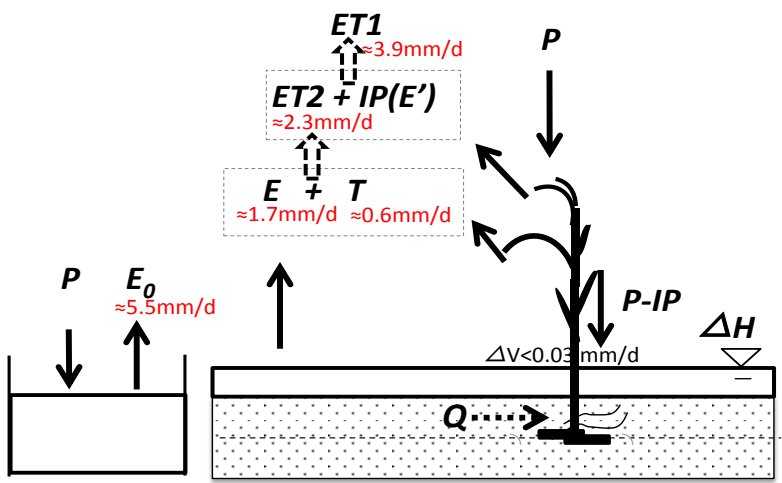

図-9 灌泊期における蒸発散量

(0.398)；LAIは葉面積指数である. なお前述したように 本研究では $G$ をと方る. Zhouら ${ }^{19}$ が双台湿地で6, 7月に 計測したLAIは平均3であり，それを用いると式(7)の值と Penman式第一項の比は0.3 となる。.またRoss ${ }^{20}$ は, 植生 により地面に到達する正味放射量の減少率を次式で表せ るとしている.

$$
R n s=R n \cdot \exp \{-G(\theta) \sin (b) L A I\}
$$

ここに $R_{n s}$ は植生により地面に到達する正味放射量 ; $\theta$ は 葉傾角, $G(\theta)$ は植物群落内吸光係数で, Vanyarkho ${ }^{21)}$ の計 測結果によれば莘の場合は $G(\theta)=0.5$ である ${ }^{20)} . b$ は太陽 高度角で，日照時間あるいは12時間の平均值が用いられ ることが多い ${ }^{10,22)}$. ここでは各日の $6: 00 〜 18: 00 の$ $\sin (b)$ の平均值として0.7を用いる. これらを代入すると 式(8)の值とPenman式第一項の比は0.35となる.

以上の結果から, 莘原内水面からの蒸発量 $E$ は次の上 うに推定された. 検討期間における式(5)の第一項の平均 值が $4.7 \mathrm{~mm} / \mathrm{d} て ゙ ，$ 第二項が $0.4 \mathrm{~mm} / \mathrm{d}$ となる. そこでRitchie の式から求められた比率を用いれば，重み付き平均值は $E=4.7 \times 0.3+0.4 \times(0.38 \sim 0.69)=1.56 \sim 1.69 \mathrm{~mm} / \mathrm{d}$ となり,

Rossが提案した式から求めた重み付き平均值は $E=4.7 \times$ $0.35+0.4 \times(0.38 \sim 0.69)=1.78 \sim 1.92 \mathrm{~mm} / \mathrm{d}$ となる. そこで 代表値として $E=1.7 \mathrm{~mm} / \mathrm{d}$ とた。.

以上の検討に基づき，各項の期間平均值が図-9の ように求められた. 赤の数字が5月 31 日〜 7月 10 日ま での期間の平均值である. なお 2012 年の灌泊期にお ける蒸発に関わる気象項目 (温度, 日照, 風速, 湿度) はほぼ平均的であった。 そこで6月1日から7月上旬ま でのET2 $(2.3 \mathrm{~mm} / \mathrm{d})$ を平均必要灌袥水量とすると, 6 月一か月の総量は約 $70 \mathrm{~mm}$ となる. 一方, 盤錦気象 局における過去 20 年間の 6 月平均降雨量は $74.5 \mathrm{~mm}$ で, 降雨遮断を考慮して0.6を乗じると, 葦原水面に達寸 る雨量は約 $45 \mathrm{~mm}$ 程度となり, 蒸発散量を下回る. したがって，7月の雨期になるまでは，水深換算で $30 \mathrm{~mm}$ 程度の灌溉が必要であるといえる.

\section{5. おわりに}

ここにEは莘原内水面からの蒸発量 ; $\alpha$ は経験定数 
丹頂など大型の水鳥の営巣地である河口湿地葦原の保 全と地域経済発展を両立する一つの方法として，葦を用 いた製紙業の育成が考えられるし葦の品質を維持には, 塩分低下と土壌水分維持のために灌潛を行う必要がある が，葦原灌湶については今のところ研究がほとんどされ ていない，そこで本研究では，双台河口湿地において， 灌溉が葦原に及ぼす効果を, 現地調査に基づき検討した. 主要な結論は以下のとおりである.

1) 土壌塩分と蔁の収量には明確な負の相関があり, 土壌塩分 $(T D S)$ が $5 \%$ 以上になると収量は減少した。 このことは，Lissner ら 7)が実験的に求めた結果と 一致している.

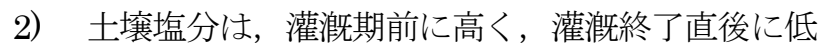
く，その後増大した．灌溉直後の塩分 $(3 \%$ ) は前述 の塩分影響レベル(5\%)より明らかに下がっていた. したがって，葦原灌泊は，塩分低下による葦の収 量増加に貢献していると考えられる.

3) 雨量が不足する 5 月末〜 7 月初旬における莘原の 蒸発散は平均で約 $3.9 \mathrm{~mm} / \mathrm{d}$ であったが，葦の葉な どで遮断された雨滴が直接蒸発する分が $1.6 \mathrm{~mm}$ あ るため, 必要灌涀量は $2.3 \mathrm{~mm} /$ day $(70 \mathrm{~mm} / \mathrm{month})$ の オーダであった.

4) 葦の成長期である 6 月の降雨量は $75 \mathrm{~mm} / \mathrm{month}$ 程 度だが，その 40\%は葦の葉に遮断され大気に直接 蒸発するので, 有効雨量は $45 \mathrm{~mm} / \mathrm{month}$ である. 有効降雨と蒸発散の比較から，6月には平均的な 降雨量の年でも灌溉が必要であるといえる.

\section{参考文献}

1) Cui, B.S, Tang, N, Zhao, X.S. and Bai, J.: A management-oriented valuation method to determine ecological water requirement for wetland in the Yellow River Delta of China, J. Nat. Conserv., Vol.17(3), pp.129-141, 2009.

2) 詹懷宇: 我国製紙用非木材繊維，古紙原料の供給及び利用, 日中紙パルプ技術交流シンポジウム論文集, 第 3 回., 紙パ ルプ技術協会, 2010 .

3) Burdick, D.M, Buchsbaus, R. and Holt, E.: Variation in soil salinity associated with expansion of Phragmites australis in salt marshes, Environ. Exp. Bot., Vol.46, pp.247-261, 2001.

4) Chambers, R.M, Osgood, D.T, Bart, D.J. and Montalto, F.: Phragmites australis invasion and expansion in tidal wetlands: interactions among salinity, sulfide, and hydrology, Estuaries., Vol.26(2B), pp.398-406, 2003.

5) Zhou, L. and Zhou, G.S.: Measurement and modeling of evapotranspiration over a reed (Phragmites australis) marsh in Northeast China, J. Hydrol., Vol.372, pp.41-47, 2009.

6) Lissner, J. and Schierup, H.H.: Effects of salinity on the growth of Phragmites australis, Aquat. Bot., Vol.55, pp.247-260, 1997.

7) Lissner, J, Schierup, H.H, Comín, F.A. and Astorga, V.: Effect of climate on the salt tolerance of two Phragmites australis. I.
Growth, inorganic solutes, nitrogen relations and osmoregulation, Aquat. Bot., Vol.64, pp.317-333, 1999.

8) Mauchamp, A. and Mésleard, F.: Salt tolerance in Phragmites australis populations form coastal Mediterranean marshes, Aquat. Bot., Vol.70, pp.39-52, 2001.

9) Hartzendorf, T. and Rolletschek, H.: Effects of NaCl-salinity on amino acid and carbohydrate contents of Phragmites australis, Aquat Bot., Vol.69, pp.195-208, 2001.

10) Rhoades, J.D, Chenduvi, F. and Lesch, S.: Soil salinity assessment-Methods and interpretation of electrical conductivity measurements, FAO Irrigation and Drainage Paper.57, pp.5-14, 1999.

11) Khorsandi, F. and Yazdi, F.A.: Estimation of saturated paste extracts' electrical conductivity from 1:5 soil/water suspension and gypsum, Commun. Soil Sci. Plant Anal., Vol.42, pp.315-321, 2011.

12) Sonmez, S, Buyuktas, D, Okturen, F. and Citak, S.: Assessment of different soil to water ratios (1:1, 1:2.5, 1:5) in soil salinity studies, Geoderma., Vol.144, pp.361-369, 2008.

13) 林倩, 石川忠晴, 赤穂良輔, 楊凰林, 張樹深 : 中国の双台 湿地莘原における灌激期後の土壤水分変化, 土木学会論文 集 B1(水工学), Vol.69, No.4, I_529-I_534, 2013.

14) 米田茂男, 河内知道: 干拓地土壌に関寸る研究, 岡山大学 農業部学術報告, Vol.11, pp.1-14, 1958.

15) Penman, H.L.: Natural evaporation from open water, bare soil and grass. Proc. Roy. Soc. London. A., Vol.193, pp.120-146, 1948.

16) Burba, G.G, Verma, S.B. and Kim, J. Surface energy fluxes of Phragmites australis in a prairie wetland, Agric. For. Meteorol., Vol.94, pp.31-51, 1999.

17) Ritchie, J.T.: Model for predicting evaporation from a row crop with incomplete cover, Water Resour. Res., Vol.8, pp.1204-1213, 1972.

18) Lövstedt, C.B. and Bengtsson, L.: Density-driven current between reed belts and open water in a shallow lake. Water Resour. Res., Vol.44, W10413, doi: 10.1029/2008WR006949, 2008.

19) Zhou, L, Zhou, G.S, Liu. S. and Sui, X.H.: Seasonal contribution and interannual variation of evapotranspiration over a reed marsh (Phragmits australis) in Northeast China from 3-year eddy covariance data, Hydrol. Process., Vol.24, pp.1039-1047, 2010.

20) Ross, J.: Mathematical models of photosynthesis in a plant stand. In Predictions and measurement of photosynthetic productivity, Wageningen, pp.29-45, 1970.

21) Vanyarkho, O.: Seasonal changes in vegetative characteristics and gas exchange of phragmites australis and Scirpus acutus in midlatitude prairie wetland ecosystem. M.S. Thesis. University of Nebraska-Lincoln, NE, pp.85, 1996.

22) Norman, J.M. et al.: Surface flux estimation using radiometric temperature: A dual-temperature-difference method to minimize measurement errors. Water Resour. Res., Vol.36(8), pp. 2263$2274,2000$.

(2013.9. 30 受付) 